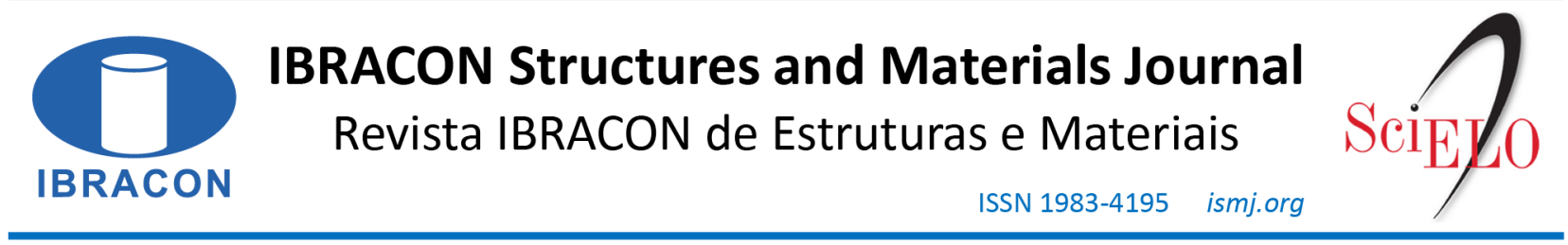

ORIGINAL ARTICLE

\title{
Analysis of constructive parameters of vertical reinforced concrete structure with self-compacting concrete
}

\section{Análise de parâmetros construtivos de estrutura de concreto armado vertical com concreto autoadensável}

\author{
Jordana Herbster Ferraz Serra ${ }^{\mathrm{a}}$ \\ Antonio Eduardo Bezerra Cabral ${ }^{\mathrm{a}}$
}

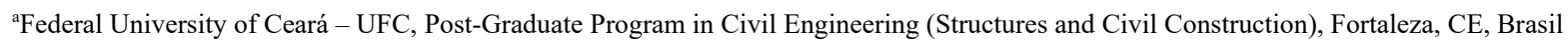

Received 15 November 2018

Accepted 07 April 2019

\begin{abstract}
The objective of this paper is to quantify the improvements due to the use of self-compacting concrete (SCC) as a replacement to a conventional Portland Cement Concrete (PCC) in the production of a reinforced concrete structure of a typical residential building in Brazil. To achieve the proposed objectives, a SCC mix was developed in the laboratory and tests were performed in the fresh and hardened states. Two floors, consisting of columns, beams and slabs, were built with SCC and a third with PCC. Pouring time and its generated noise, appearance of pathological manifestations after pouring, amount of labor required for pouring, costs and the risk of work-related accidents were evaluated. The results indicate that the floors produced with the SCC obtained $60.5 \%$ less pouring time, a reduction of $50 \%$ and $62.8 \%$ in the quantity and costs of labor, respectively; $260.8 \%$ reduction in the accident risk factor and, finally, a reduction of $56.4 \%$ in the total cost.
\end{abstract}

Keywords: self-compacting concrete, productivity, unit production ratio, costs.

Resumo: O objetivo deste artigo é quantificar as possíveis melhorias do uso do concreto autoadensável (CAA) em substituição ao concreto convencional plástico $(\mathrm{CCV})$ na produção de uma estrutura de concreto armado de edificação vertical típica do Brasil. Para se atingir os objetivos propostos, um traço de CAA foi desenvolvido em laboratório, tendo sido executados ensaios no estado fresco e no estado endurecido. Dois pavimentos, constituídos de pilares, vigas e lajes, foram executadas em CAA e um terceiro foi executado em $\mathrm{CCV}$. O tempo de concretagem e seu ruído gerado, o aparecimento de manifestações patológicas posteriormente à concretagem, a quantidade de mão de obra necessária para a concretagem, os custos e o risco de acidentes de trabalho foram avaliados. Os resultados obtidos indicam que os pavimentos produzidos com o CAA obtiveram tempo de concretagem $60,5 \%$ menor, redução de $50 \%$ e $62,8 \%$ na quantidade e custos de mão de obra, respectivamente, redução de $260,8 \%$ no fator de risco de acidentes e, por fim, uma redução no custo total de $56,4 \%$.

Palavras-chave: concreto autoadensável, produtividade, RUP, custos.

How to cite: J. H. F. Serra, A. E. B. Cabral, “Analysis of constructive parameters of vertical reinforced concrete structure with self-compacting concrete," IBRACON Struct. Mater. J., vol. 13, no. 5, e13501, 2020, https://doi.org/10.1590/S1983-41952020000500001

\section{INTRODUCTION}

Self-compacting concrete (SCC) is already used in several countries, representing one of the greatest advances in concrete technology in recent decades. The SCC has the capacity to fill in all the spaces destined to it in the mold on its own. It does not require any external intervention or vibration, and it does not segregate or trap an excessive amount of air. Thus, its application is easier, faster, avoids pathological manifestations such as concreting nests, as well as eliminates the noise caused by vibrators. Additionally, it is possible to build more durable and economical structures by using SCC [1], [2]. 
Moreover, the use of SCC can also reduce the number of employees needed to carry out the concrete pouring, as it does not require any vibration nor spreading. In addition to shortening the pouring time, the use of SCC in construction buildings can potentially reduce the risk of the workers falling during the pouring spreading and vibrating phases [2].

To be classified as a SCC, the concrete must fulfill three requirements simultaneously: fluidity, passing ability and resistance to segregation [3]. In order to assure the proper behavior of the SCC in the fresh state, it is necessary to carry out the tests prescribed in ABNT NBR 15823, so that, once these requirements are met, it is also possible to meet the requirements for the concrete's hardened state. The structure of SCC is denser than one of conventional Portland cement concrete (PCC), in other words, there is less void volume, which provides a better adhesion between concrete and steel [4]. This can also contribute to a better mechanical behavior of the structural elements produced with SCC when compared to those produced with PCC.

SCC is vastly used in the precast concrete industry due to its better adjustment to variations in shape relatively to the PCC. In addition, the production in a precast concrete plant is more controlled than at construction sites. However, the employment of SCC is restricted to complex projects and special structures, since it can be dosed in construction sites or in concrete plants, with the same ease in manufacturing. [5].

In addition to SCC applications in the production of precast parts, there are examples of applications in tunnels, overpasses and roads in several countries, such as Sweden and France, where this concrete technology is widely used in the repair and structural strengthening of old structures, where the use of vibration is not advised, due to the risk of worsening the state of the structure. An example of this application is The Katelbridge bridge, in the Netherlands, which was repaired after 45 years of service, in 2002 [6].

Along with the advantages of the finished material, the use of SCC may turn out to be a way to enhance the productivity during the concreting of vertical projects, in view of the reduction of the manpower and waiting periods between concrete trucks, which results in a reduction on the overall construction cost. Brazilian civil construction has its own characteristics, with a focus on high employment of labor force [7]. However, there is no Brazilian standard to measure the productivity indexes for concrete pouring, making each company search for its own indexes, often with different criteria, so that comparison between companies is oftentimes difficult or even impossible.

Even with various advantages, there are still not many records of SCC use in Brazil, especially in vertical constructions. Although there is an increase, its use is still small, but the potential for expanding grows every day through research and practical applications. Therefore, the lack of studies, the need to adapt the technology to the construction reality in Brazil and, customarily, the higher cost of this type of concrete, are the main reasons why there are still few works that have used this constructive technology [8].

Hence, the objective of this article is to evaluate the use of self-compacting concrete to replace conventional concrete in a vertical building project in Brazil. The study was divided into the following stages: design of a selfcompacting concrete mix with local materials, so that it meets the criteria in NBR 15823; applying the selfcompacting concrete in a vertical construction, evaluating concreting time, amount of labor force needed, possible pathological manifestations in the structure and the related costs; comparing these data to those of regular Portland Cement Concrete.

\section{METHODOLOGY}

The methodology was divided into three stages. The first refers to the SCC laboratory mix design; the second, regards the application of the SCC in a vertical construction building; and the third, encompasses the comparative analysis between SCC and PCC, through the determination of indices.

\subsection{SCC mix design at the laboratory}

In the SCC mix design, it was used a Brazilian Portland cement type CP II F 32 with the physical and chemical characteristics shown in Table 1. 
Table 1. Chemical and physical characteristics of used cement.

\begin{tabular}{|c|c|c|}
\hline \multicolumn{3}{|c|}{ Chemical composition (\%) } \\
\hline & & ards limits (NBR 11578) \\
\hline Loss of ignition & $4.90 \%$ & $<6.5 \%$ \\
\hline $\mathrm{MgO}$ content & $3.41 \%$ & $<6.5 \%$ \\
\hline $\mathrm{SO}_{3}$ content & $3.15 \%$ & $<4.0 \%$ \\
\hline $\mathrm{Fe}_{2} \mathrm{O}_{3}$ content & $3.25 \%$ & - \\
\hline $\mathrm{Al}_{2} \mathrm{O}_{3}$ content & $4.45 \%$ & - \\
\hline $\mathrm{CaO}$ content & $60.67 \%$ & - \\
\hline $\mathrm{SiO}_{2}$ content & $19.48 \%$ & - \\
\hline Insoluble waste & $1.94 \%$ & $<2.5 \%$ \\
\hline \multicolumn{3}{|c|}{ Physical properties } \\
\hline Compressive strength & & Standards limits \\
\hline 3 days & $31.5 \mathrm{MPa}$ & $>10 \mathrm{MPa}$ \\
\hline 7 days & $35.3 \mathrm{MPa}$ & $>20 \mathrm{MPa}$ \\
\hline 28 days & 39.4 MPa & $>32 \mathrm{MPa}$ \\
\hline \multicolumn{3}{|l|}{ Fineness } \\
\hline$\# 200$ & $1.83 \%$ & $<12 \%$ \\
\hline$\# 325$ & $9.33 \%$ & Not applicable \\
\hline Blaine & $4568 \mathrm{~cm}^{2} / \mathrm{g}$ & $>2600 \mathrm{~cm}^{2} / \mathrm{g}$ \\
\hline Consistency water & $27.49 \%$ & Not applicable \\
\hline \multicolumn{3}{|l|}{ Setting time } \\
\hline Begin & $2 \mathrm{~h}: 05 \mathrm{~min}$ & $>1 \mathrm{~h}$ \\
\hline End & 3h:04min & $<10 \mathrm{~h}$ \\
\hline Hot expansibility & $0.38 \mathrm{~mm}$ & $<5 \mathrm{~mm}$ \\
\hline
\end{tabular}

The fine aggregate used was a quartz sand from a riverbed and the coarse aggregate was of granitic origin. The characteristics of the aggregates are shown in Table 2.

Table 2. Characterization of aggregates.

\begin{tabular}{|c|c|c|c|c|}
\hline \multicolumn{5}{|c|}{ Granulometry } \\
\hline \multirow{2}{*}{ Sieve \# } & \multicolumn{2}{|c|}{ Fine (sand) } & \multicolumn{2}{|c|}{ Coarse (gravel) } \\
\hline & $\%$ Average Retained & $\%$ Retained Accumulated & $\%$ Average Retained & $\%$ Retained Accumulated \\
\hline 12.7 & - & - & 0.3 & 0 \\
\hline 9.5 & - & - & 11.8 & 12 \\
\hline 6.3 & - & - & 46.1 & 58 \\
\hline 4.8 & 8 & 8 & 20.5 & 78.6 \\
\hline 2.36 & 5 & 13 & 16.6 & 95.2 \\
\hline 1.18 & 13.7 & 26.7 & 2.6 & 97.8 \\
\hline 0.6 & 33.7 & 60.4 & 0.5 & 98.3 \\
\hline 0.3 & 30.9 & 91.3 & 0.5 & 98.8 \\
\hline 0.15 & 5.4 & 96.7 & 1.2 & 100 \\
\hline Bottom & 3 & 100 & 0 & - \\
\hline Maximum Dimension & \multicolumn{2}{|r|}{$6.3 \mathrm{~mm}$} & \multicolumn{2}{|r|}{12.7} \\
\hline F.M. & \multicolumn{2}{|c|}{2.96} & \multicolumn{2}{|r|}{5.8} \\
\hline \multicolumn{5}{|c|}{ Physical Indexes } \\
\hline & Sand & Standard method & Gravel & Standard method \\
\hline Specific gravity & $2.60 \mathrm{~g} / \mathrm{cm}^{3}$ & NBR NM 52 e 53 & $2.69 \mathrm{~g} / \mathrm{cm}^{3}$ & NBR NM 52 e 53 \\
\hline Bulk density & $1.52 \mathrm{~g} / \mathrm{cm}^{3}$ & NBR NM 45 & $1.45 \mathrm{~g} / \mathrm{cm}^{3}$ & NBR NM 45 \\
\hline
\end{tabular}


The mineral addition used was cretaceous natural calcium carbonate, of marine sedimentary origin, with high purity, which is applied as filler in many products. It presents a crystalline structure and its specific density is $2.70 \mathrm{~g} / \mathrm{cm}^{3}$, according to the supplier. Its physical and chemical characteristics are described in Table 3.

Table 3. Characterization of limestone filler used in the production of SCC.

\begin{tabular}{|c|c|}
\hline \multicolumn{2}{|c|}{ Physical characteristics } \\
\hline Humidity $(\%)$ & 0.3 \\
\hline Bulk density $\left(\mathrm{g} / \mathrm{cm}^{3}\right)$ & 1.2 \\
\hline $\mathrm{pH}$ & 9 \\
\hline \multicolumn{2}{|c|}{ Chemical Characteristics } \\
\hline $\mathrm{CaCO}_{3}(\%)$ & 92.5 \\
\hline $\mathrm{CaO}(\%)$ & 52.5 \\
\hline $\mathrm{Fe}_{2} \mathrm{O}_{3}(\%)$ & 0.05 \\
\hline $\mathrm{Al}_{2} \mathrm{O}_{3}(\%)$ & 0.03 \\
\hline $\mathrm{SiO}_{2}(\%)$ & 0.35 \\
\hline $\mathrm{MgO}(\%)$ & 1.5 \\
\hline $\mathrm{Pb}(\mathrm{mg} / \mathrm{g})$ & 0.06 \\
\hline $\mathrm{Cd}(\mathrm{mg} / \mathrm{g})$ & 0.009 \\
\hline Loss of ignition $\left(900^{\circ} \mathrm{C}\right)(\%)$ & 42.5 \\
\hline
\end{tabular}

The chemical admixtures used in this research were: a third generation superplasticizer based on polycarboxylate, free of chlorides, with $40 \%$ of solids, density of $1.1 \mathrm{~g} / \mathrm{cm}^{3}, \mathrm{pH}$ equal to 6 and soluble in water; and a setting time retardant multifunction plasticizer as a dispersing agent for cement particles, with a density of $1.2 \mathrm{~g} / \mathrm{cm}^{3}, \mathrm{pH}$ equal to 9 and soluble in water. The information regarding the admixtures was provided by the manufacturer. The water used in the tests came from the public supply system in the city of Fortaleza, Brazil.

The concrete mix design was based on the method proposed by Gomes [9]. This method is divided into three phases: obtaining the composition of the paste, determining the proportion of the mixture, and selecting paste content. The mix was designed for a $30 \mathrm{MPa}$ characteristic strength $\left(f_{\mathrm{ck}}\right)$ at 28 days.

Table 4 shows the PCC mix, from the concrete plant hired by the construction, and the SCC mix, which was obtained in the laboratory and later adapted for the concrete plant to suit the needs of the construction and the concrete supplier.

Table 4. Concrete mixtures.

\begin{tabular}{|c|c|c|}
\hline Material & PCC & SCC \\
\hline Cement (kg) & 349 & 406 \\
\hline Limestone filler $(\mathrm{kg})$ & - & 125 \\
\hline Sand $(\mathrm{kg})$ & 787 & 779 \\
\hline Gravel type $1(\mathrm{~kg})$ & 749 & - \\
\hline Gravel type $0(\mathrm{~kg})$ & 249 & - \\
\hline Gravel 9,5 (kg) & - & 819 \\
\hline Gravel 12,7 (kg) & - & - \\
\hline Superplasticizer (L) & 2.16 & 2.7 \\
\hline Plasticizer (L) & - & 2 \\
\hline Water (L) & 188 & 200 \\
\hline
\end{tabular}

\subsection{Case study of SCC application in a vertical construction building}

The case study was carried out in a vertical construction building, in Fortaleza, Brazil. SCC was poured in two floors, and PCC pouring was performed once, for comparison, as follows:

- First SCC pouring: slab and beams from the 4 th floor, columns and stairs from the $3^{\text {rd }}$ to the $4^{\text {th }}$ floor; 
- Second SCC pouring: slab and beams from the 5th floor, columns and stairs from the $4^{\text {th }}$ to the $5^{\text {th }}$ floor;

- PCC pouring: slab and beams from the 6 th floor, columns and stairs from the $5^{\text {th }}$ to the $6^{\text {th }}$ floor.

The concrete supplier was the same for both types of concrete.

Concrete volume per floor is $105.6 \mathrm{~m}^{3}$, divided into $61 \mathrm{~m}^{3}$ for slabs, $27.5 \mathrm{~m}^{3}$ for beams, $16 \mathrm{~m}^{3}$ for columns and $1.1 \mathrm{~m}^{3}$ for stairs. Figure 1 shows the floor plant on which the concreting took place. The characteristic strength of both concretes (SCC and PCC) was $30 \mathrm{MPa}$.

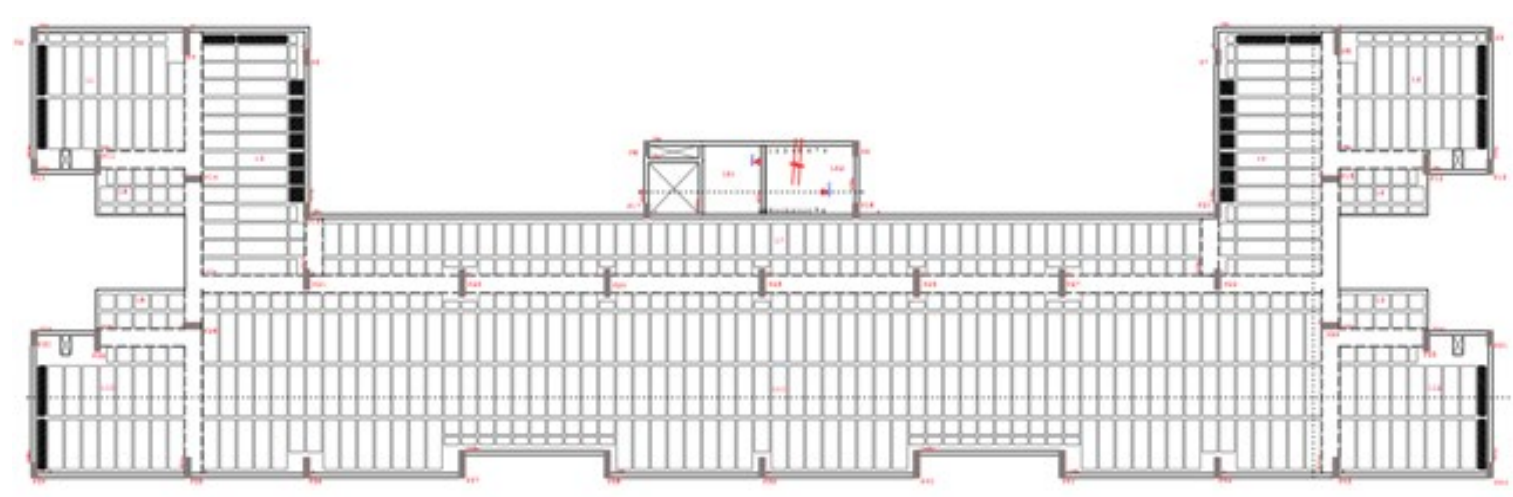

Figure 1. Floor plant.

After the superficial hardening of the concrete, a $5 \mathrm{~mm}$ layer of water was kept on the slab for 3 days to prevent the loss of water from the concrete (wet curing). After this period, for another 4 days the concrete was watered at least twice a day.

Slump test for the PCC and slump flow, L-Box and Funnel V tests for the SCC were carried out, according to respective Brazilian standards. For each concrete mixer truck, 6 cylindrical specimens $(10 \times 20) \mathrm{cm}$ (diameter x height) were molded to test the compressive strength at 3, 7 and 28 days. However, the specimens that were supposed to be tested on the $3^{\text {rd }}$ day were tested only on the $4^{\text {th }}$ and $5^{\text {th }}$ days due to some holidays.

\subsection{Comparative analysis of SCC and PCC indexes}

In order to analyze productivity, the advantages and disadvantages of using the SCC in comparison to PCC in the execution of the concrete parts of the vertical building, the following items were analyzed and considered: amount of labor force and the its related costs; work safety; amount of tools and equipment used during the pouring; total time and costs to complete the concrete parts. Descriptions of each indicator are as follows:

\section{- Labor force}

Labor productivity was measured by a partial index called Unit Production Ratio (UPR), which corresponds to the ratio of the number of worker-hours (Wh) spent to perform a given service, in this case the volume of concrete poured and finished, over the amount of service performed (Equation 1). It is important to note that the higher the value of the UPR, the worse the productivity [10].

$U P R=W h / Q$

Where UPR = unit production ratio; Wh = number of workers times the number of hours of service; $\mathrm{Q}=$ quantity of service, which, in this case, is the volume of concrete used.

The UPR considered for the concreting service was the cyclic UPR, in which the service execution cycle is analyzed [11]. It was necessary to homogenize the means of UPR evaluation, and four aspects were standardized: definitions of which collaborators (workers) and their role in the construction are included in the evaluation; the quantification of the hours of work to be considered (hours); the quantification of the service (volume of concrete); and the definition of the time period to which the input and output measurements refer. Three UPRs were calculated: the first one contemplates only 
the time to cast the concrete; the second one added the waiting time between the concrete mixer trucks; and the third one covers, in addition to the two periods mentioned, the waiting time for the arrival of the $1^{\text {st }}$ truck.

The number of hours spent from the beginning to the end of the concrete casting was considered, linked to the value worker/hour. The time and cost of labor for analysis was considered up to the moment when the concreting reached 88 $\mathrm{m}^{3}$ in all concretes, as it would make possible to compare SCC more accurately to PCC. This volume of concrete was defined due to the impossibility of completing the $1^{\text {st }}$ and $2^{\text {nd }}$ concreting with SCC in the whole floor, due to the lack of concrete inputs (lack of mineral addition).

The administration staff of the construction was the same for the three concreting, which was formed by an engineer, a building technician, a work safety technician, a supervisor, a construction foreman and a civil engineering undergraduate student. Despite being the same work force for all pourings, the cost increases according to the pouring time. The worker-hour value of each employee mentioned was taken as their respective salaries and charges provided by the construction company.

However, the number of employees directly involved in the process varied. In the first pouring, the number of workers was higher as a precaution, as it was the first time that the construction company would use SCC and there was a fear that something unforeseen would arise in relation to the compacting of the concrete and that it would be necessary to use the PCC again. Although there were no problems in that regard, it was necessary to use PCC to complete the concreting, as the amount of mineral addition was not enough to produce all the SCC needed. In the second concreting, now more confident, the number of employees directly involved in the concreting was reduced. In concrete pouring with SCC, the number of workers was the standard for the work - already used for the other slabs of the same project. The distribution of employees by function is shown in Table 5.

Table 5. Distribution of non-administrative collaborators of the work in the 3 concreting.

\begin{tabular}{ccccc}
\hline \multirow{2}{*}{ Office } & \multicolumn{3}{c}{ Number of workers } & Occupation \\
\cline { 2 - 4 } & $\mathbf{1}^{\text {a }} \mathbf{S C C}$ & $\mathbf{2}^{\mathbf{a}} \mathbf{S C C}$ & $\mathbf{C P C}$ & Hardware monitoring \\
\hline Blacksmith & 1 & 1 & 1 & Review of forms \\
\hline Carpenter & 1 & 1 & 2 & Scraping \\
\hline Masons & 2 & 2 & 3 & Pump hose boom \\
\hline Servant & 1 & 1 & 1 & Pulling / lathing the concrete \\
\hline Servant & 4 & 2 & 4 & Vibrator \\
\hline Servant & - & - & 4 & Maintenance of vibrators / possible temporary installation \\
\hline Aux. Electrician & - & - & 1 & \\
\hline TOTAL & 9 & 7 & 16 &
\end{tabular}

\section{- Accidents at work}

An index was determined to measure the possibility of accidents at work due to falls at the time of pouring, the number of employees working at height versus the time needed to complete their activities. That is, the risk of accidents at work due to falls from height is the amount of time worked at height times the number of employees.

\section{- Tools and equipment}

To measure and evaluate the use of tools and equipment, the following data was recorded: delays in the concrete mixer truck due to equipment breakage or due to the return of a concrete truck; time to unload each truck; waiting time for each truck; total pouring time, from the beginning of the unloading of the first truck to the end of the last; rental value of vibrators, where the amount of $\mathrm{R} \$ 66.00$ per work-day for each equipment was considered; value of the unit volume of the concrete charged by the concrete company (R\$280.0 for the PCC and R $\$ 332.50$ for the SCC).

\section{RESULTS}

\subsection{SCC mix design}

The results of the tests carried out in the fresh state for the acceptance of the mix designed in the laboratory and adjusted in the concrete plant are shown in Table 6. The results of the tests carried out in the hardened state are shown 
in Table 7. A small dimension column was molded $(20 \mathrm{~cm} \times 20 \mathrm{~cm} \times 1.5 \mathrm{~m})$ in the laboratory, for which was observed a smooth finish, free of bubbles or concrete failures, indicating the good self-compacting ability of the concrete.

Figure 2 shows the L-Box test in the laboratory. It is observed that the concrete passed through the obstacles without blocking the passage. Figure 3 shows the SCC's edge after the slump flow test, in which it is observed that the concrete is cohesive and without segregation. Figure 4 shows the appearance of the SCC at the time of pouring on the slab.

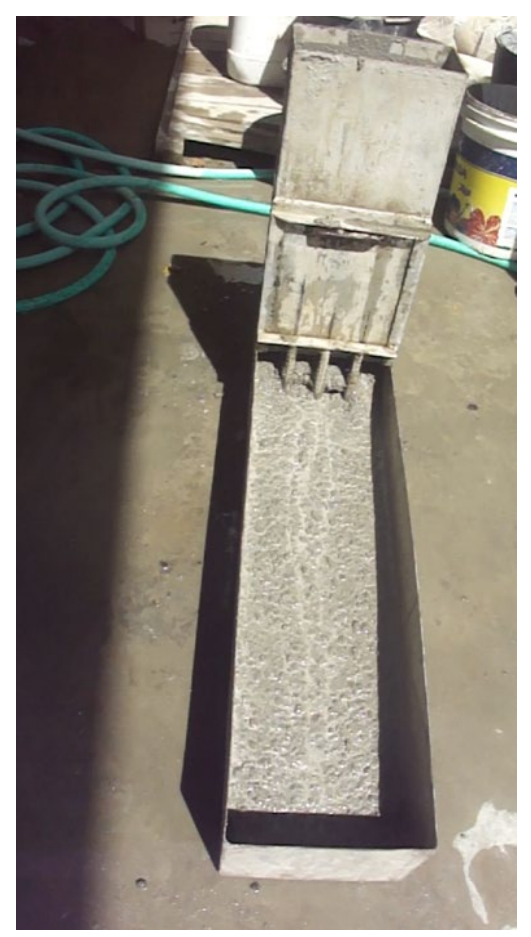

Figure 2. L-Box test in laboratory.

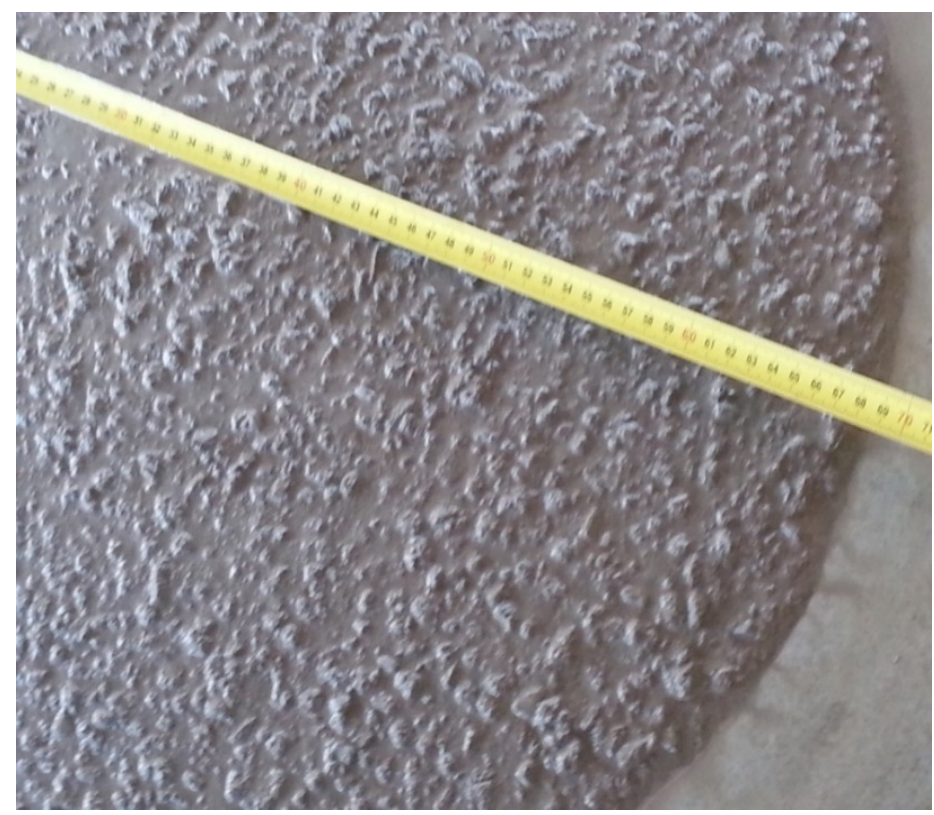

Figure 3. Focus on the end of the SCC in the slump flow trial. 
Table 6. Result of SCC tests in the fresh state.

\begin{tabular}{|c|c|c|c|c|c|}
\hline \multirow{2}{*}{ Test } & \multirow{2}{*}{ Laboratory SCC } & \multicolumn{2}{|c|}{$\mathrm{SCC}$ in the site } & \multirow{2}{*}{ Classification } & \multirow{2}{*}{ Test Method } \\
\hline & & $1^{a}$ pouring & $2^{a}$ pouring & & \\
\hline Slump Flow & $690 \mathrm{~mm}$ & $677 \mathrm{~mm}$ & $675 \mathrm{~mm}$ & SF 2 & $\mathrm{ABNT}, 2010 \mathrm{a}$ \\
\hline $\mathrm{T}_{500}$ & $1.8 \mathrm{~s}$ & $1.6 \mathrm{~s}$ & $1.7 \mathrm{~s}$ & VS 1 & ABNT, $2010 \mathrm{a}$ \\
\hline $\mathrm{V}$ funnel & $5 \mathrm{~s}$ & $2.8 \mathrm{~s}$ & $3.0 \mathrm{~s}$ & VF 1 & ABNT, $2010 \mathrm{~b}$ \\
\hline L box & 0.8 & 0.8 & 0.8 & PL 2 & $\mathrm{ABNT}, 2010 \mathrm{c}$ \\
\hline $\mathrm{J}$ ring & $685 \mathrm{~mm}$ & $685 \mathrm{~mm}$ & - & PJ 2 & ABNT, $2010 \mathrm{f}$ \\
\hline
\end{tabular}

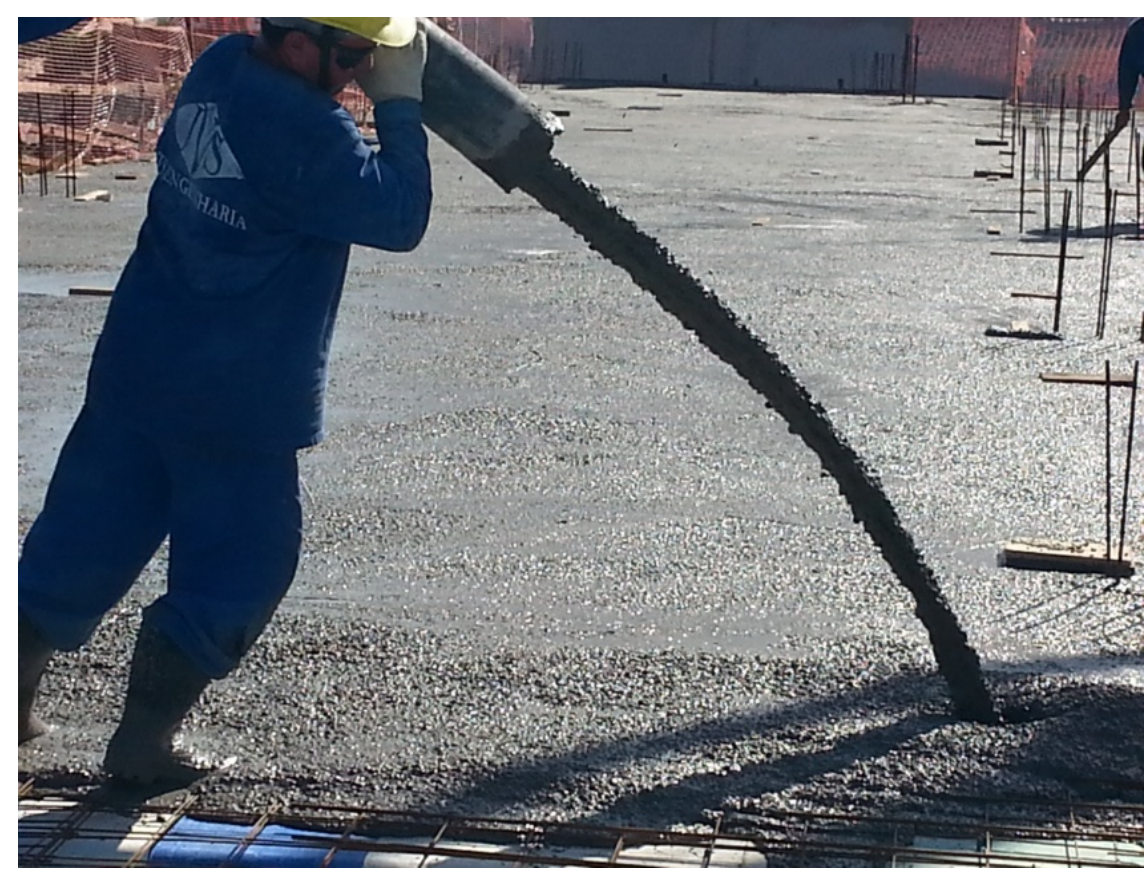

Figure 4. SCC pouring in the site.

According to data in Table 7, the compressive strength of SCC at 3 days already represents, on average, $90 \%$ of the $\mathrm{f}_{\mathrm{ck}}$ value, which is $30 \mathrm{MPa}$. Thus, the construction process was improved in terms of time, considering that it was only possible to perform prestressing when the concrete reached $70 \%$ of the characteristic strength required in the project. Therefore, according to the results of compressive strength of the SCC, it would be possible to advance the prestressing work by 3 days per slab, taking into account that conventional concrete reaches $75 \%$ of the required strength only at 7 days. The strength of the SCC is greater than that of the CPC in these early ages due to the greater amount of cement and limestone filler required for the concrete to be self-compacting.

Table 7. Result of SCC tests in the hardened state.

\begin{tabular}{|c|c|c|c|c|c|}
\hline Test & $\begin{array}{l}\text { SCC at the } \\
\text { laboratory }\end{array}$ & $\begin{array}{c}\text { SSC at site - } \\
1^{\text {st }} \text { pouring }\end{array}$ & $\begin{array}{l}\text { SSC at site - } \\
2^{\text {nd }} \text { pouring }\end{array}$ & PCC at site & Test method \\
\hline Absorption & $4.65 \%$ & - & - & - & \multirow{3}{*}{ NBR 9778 (ABNT, 2009) } \\
\hline Voids index & $10.4 \%$ & - & - & - & \\
\hline Specific gravity & $2.21 \mathrm{~g} / \mathrm{cm}^{3}$ & - & - & - & \\
\hline Compressive strength at 3 days & $33.4 \mathrm{MPa}$ & $27 \mathrm{MPa}$ & $24 \mathrm{MPa}$ & $21.5 \mathrm{MPa}$ & \multirow{3}{*}{ NBR 5739 (ABNT, 2007) } \\
\hline Compressive strength at 7 days & - & $30 \mathrm{MPa}$ & $28 \mathrm{MPa}$ & $27.6 \mathrm{MPa}$ & \\
\hline Compressive strength at 28 days & $41.7 \mathrm{MPa}$ & $37 \mathrm{MPa}$ & $37 \mathrm{MPa}$ & $35 \mathrm{MPa}$ & \\
\hline
\end{tabular}




\subsection{COMPARATIVE ANALYSIS BETWEEN PCC AND SCC POURING}

Graph 1 shows the UPR of SCC and PCC pouring, considering pouring times versus the total number of employees needed. Considering only the launch time for calculating the UPR, it appears that the UPR of PCC pouring $\left(0.49 \mathrm{Wh} / \mathrm{m}^{3}\right)$ is $165 \%$ higher than the average UPR of SCC pouring $\left(0.19 \mathrm{Wh} / \mathrm{m}^{3}\right)$. If the waiting time between trucks is included in the UPR calculation, the increase is $115 \%$, and if the waiting time for the first truck to arrive since ordering is considered, as well as the waiting time between trucks, the increase is $53 \%$. So it turns out that whatever the scenario, productivity with SCC is always higher than with PCC, enabling the transfer of workers from the pouring to other services, helping to reduce the work schedule.

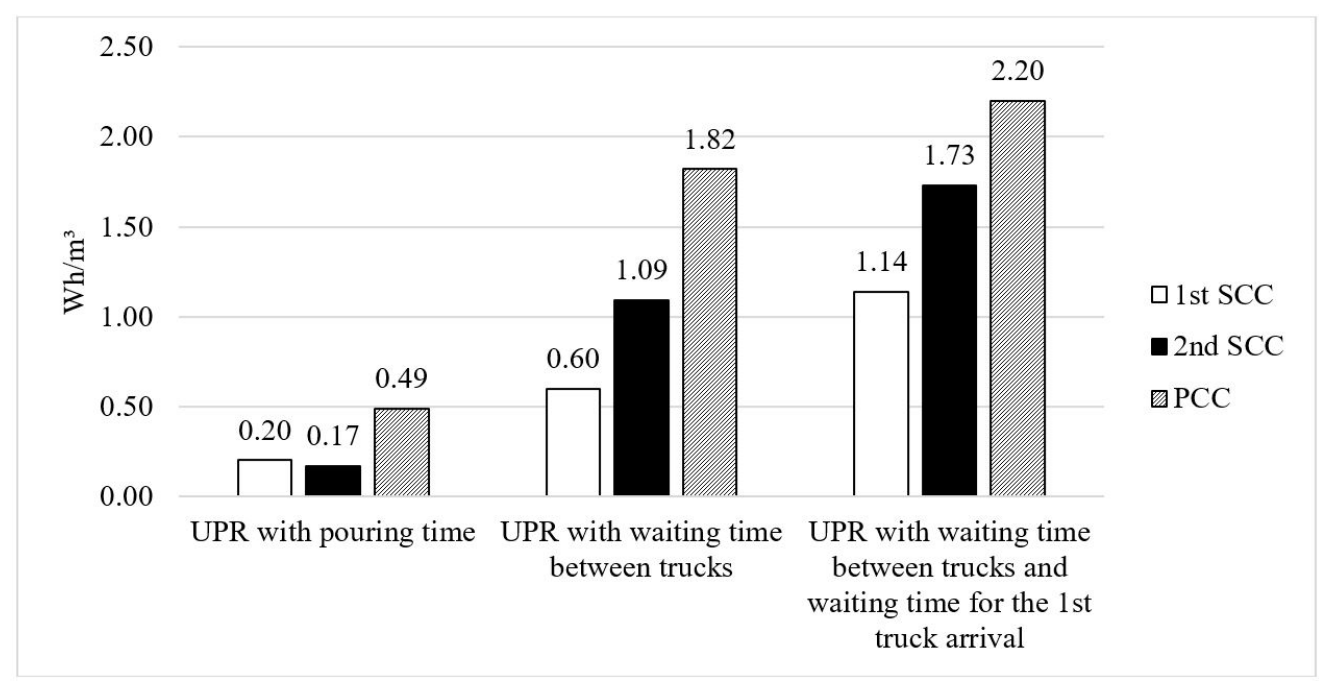

Graph 1. UPR pouring $\left(\mathrm{Wh} / \mathrm{m}^{3}\right)$.

Graph 2 shows the number of workers needed in pouring per hour and volume of concrete $\left(\mathrm{Wh} / \mathrm{m}^{3}\right)$. It is observed that PCC pouring used $221.7 \%$ more workers per hour and per concrete volume, than the average of SCC pouring. The explanation for the better performance of SCC is that, through this technology, fewer workers are needed in the pouring operation (see Table 5), since it is not necessary to vibrate the concrete, besides taking less time to pour the same volume of material.

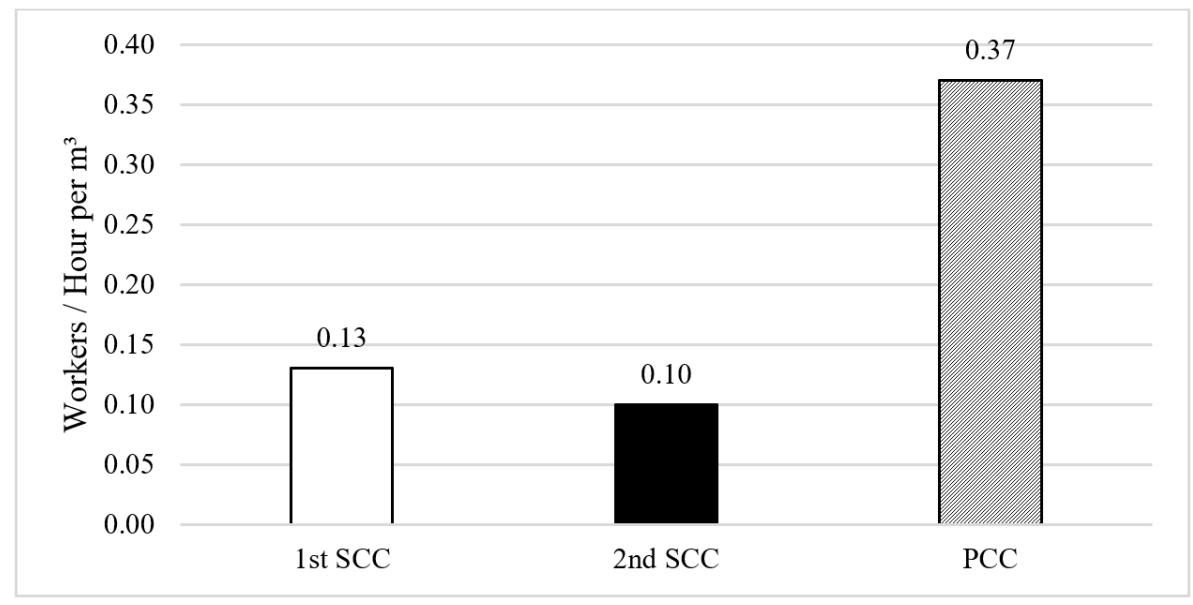

Graph 2. Number of worker per hour per $\mathrm{m}^{3}$ of concrete. 
Graph 3 shows the waiting time between trucks, the casting time of the concretes and the total time spent on each concreting.

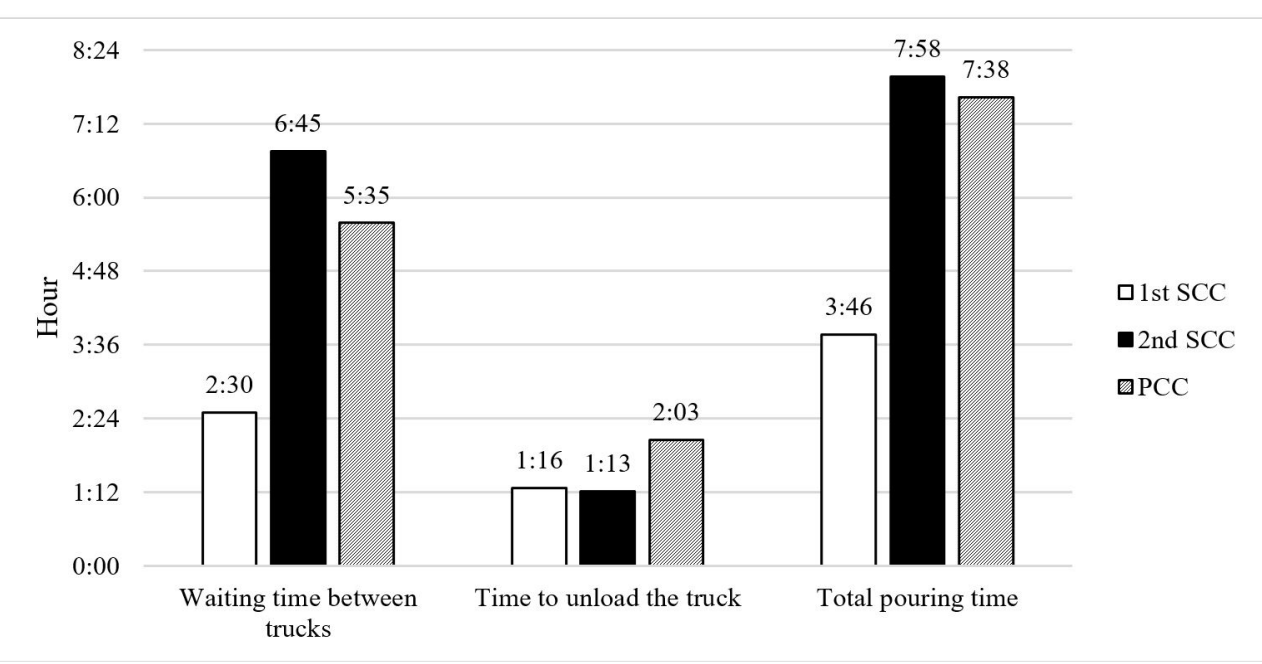

Graph 3. Total concreting time.

According to data in Graph 3, the time to unload the concrete mixer truck with the SCC is, on average, 39.4\% less than the time to unload a mixer truck of the same volume with PCC. This reduction in the discharge time for the SCC is a function of the uninterrupted pumping operation for this type of concrete, since in concretes with the PCC there are pauses for the spreading of the concrete, whereas in concretes with SCC this activity is not required.

However, there is a variable that interferes with the total concreting time that does not depend on the type of concrete, which is the waiting time between trucks. This time is related to the operational activities of the concrete company and depends on the management of its processes. In the case under study, in the first concreting with the SCC this waiting time was $55.2 \%$ less than the time spent for concreting with the PCC. However, in the second concreting with the SCC this time was $20.9 \%$ longer than that of the concreting with the PCC. The explanation for the increase of this time in the second concreting were technical difficulties of the concrete plant in simultaneously making a SCC concreting in a construction and a PCC one in another.

It is also necessary to consider the waiting time to start pouring, which is the interval between the time when the first truck was scheduled to arrive and the time when it actually arrived. These data are presented in Table 8 , in which the average waiting time is 3.5 hours for the SCC, $121 \%$ higher than waiting for concreting with the PCC. This longer time exposes the lack of mastery of the concrete plant with the initial actions to start the SCC. However, this time was not accounted for in costs since the focus of the work is the comparison between the types of concrete from the start of pouring onwards.

Table 8. Waiting time to initiate pouring.

\begin{tabular}{cc}
\hline Type of concrete & Waiting time for the beginning of pouring (hours) \\
\hline $1^{\text {st }}$ SCC & $03: 15$ \\
\hline $2^{\text {nd }}$ SCC & $04: 10$ \\
\hline PCC & $01: 35$ \\
\hline
\end{tabular}

Graph 4 shows the time of pouring, vibrating and spreading (in the case of slabs) of the concrete, in other words, the time between the start of the concrete pumping and the delivery of the finished piece. It is observed that this time is on average $39.4 \%$ shorter for concreting with SCC than for concreting with PCC, due to the absence of the vibrating step and the ease in the spreading step. However, given that it was the first time that a concreting with SCC was carried out with the construction team and, therefore, the collaborators still did not have the experience to launch, spread and finish it, it was realized that there is a possibility of reduction of the measured time, when the workforce is properly trained to handle this type of concrete. 


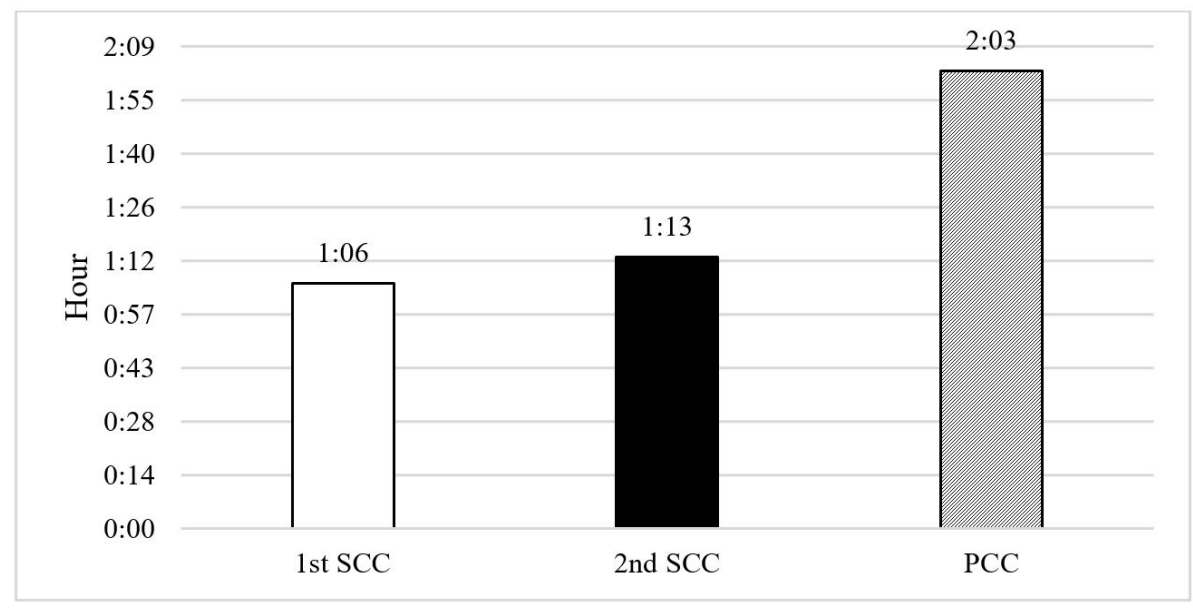

Graph 4. Time of pouring, vibrating and spreading of the concrete.

Graph 5 presents the costs with the administration staff of the construction for each concreting, considering that this cost is proportional to the time. The administration staff was described in the methodology section.

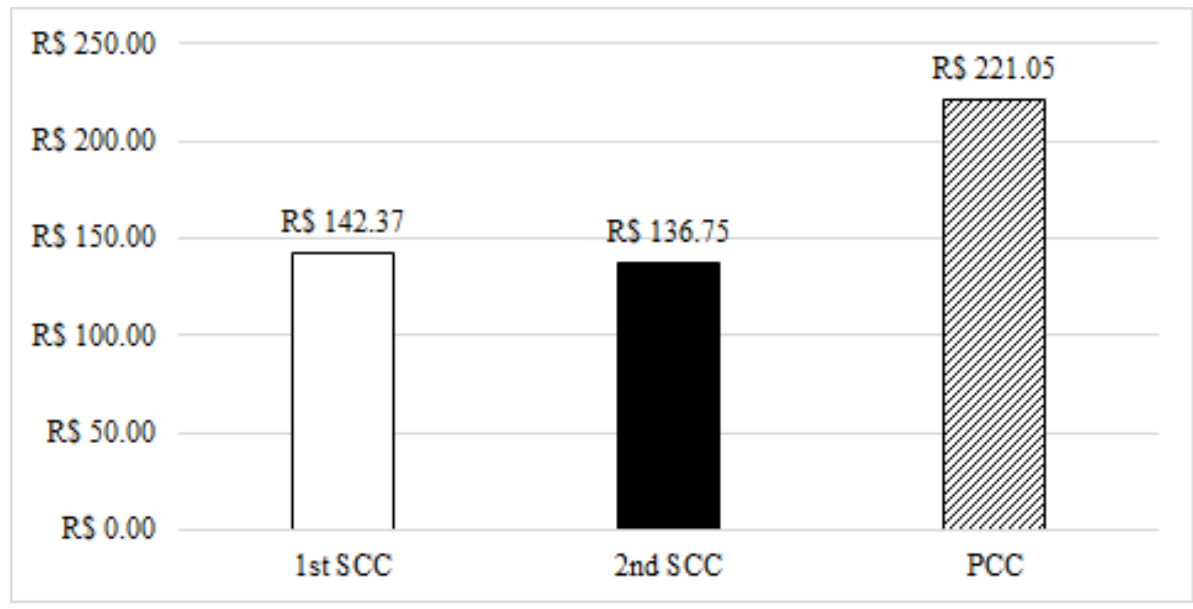

Graph 5. Total cost with administration staff.

It is possible to see in Graph 5 that the cost reduces when SCC is used due to the significant reduction in pouring time and the labor force employed. The cost with administrative staff in the $1^{\text {st }}$ and $2^{\text {nd }}$ concreting with SCC is $35.6 \%$ and $38.1 \%$ lower comparatively to that of concreting with the PCC, respectively. These values are representative, considering that the company can save an average of $36.9 \%$ with management employees by concreting. When this value is multiplied by each concreting performed by the company, the financial amount becomes significant.

Table 5, previously presented in the methodology, shows the number of employees that were required in each concreting, by function. The use of SCC reduced manpower by $43.8 \%$ in the $1^{\text {st }}$ concreting and $56.3 \%$ in the $2^{\text {nd }}$ concreting. This can be explained in part by the fact that there is no need for the use of vibrators in the SCC, thus allowing the suppression of the workers who handled this equipment and of the electrician's assistant who was on standby to fix for any damage to it. Another reason for reducing manpower is the ease of spreading the SCC. Thus, the number of workers who pulled and littered the concrete was reduced by almost half; and the number of carpenters by half, as the SCC did not accumulate on the moulds, reducing the risk of their rupture. Also, according to Table 5, it appears that the number of workers in the $1^{\text {st }}$ concreting with the SCC is greater than that of the $2^{\text {nd }}$ concreting. The reason for this is that the construction company, apprehensive about the new method, placed spare employees in the $1^{\text {st }}$ 
concreting so that there were no unforeseen events that would prevent the execution of the concreting of the planned pieces.

As already stated in the methodology, the costs were elaborated considering a concrete volume of $88 \mathrm{~m}^{3}$ in each execution, as this way the comparison is in accordance to the $2^{\text {nd }}$ day of the SCC, considering that the concreting with SCC of the $1^{\text {st }}$ day was greater than that of the $2^{\text {nd }}$ day. Graph 6 shows the cost of field labor for each concreting. The reduction in the number of employees involved with concreting provided by the use of SCC resulted in an average reduction of $75.7 \%$ in labor costs.

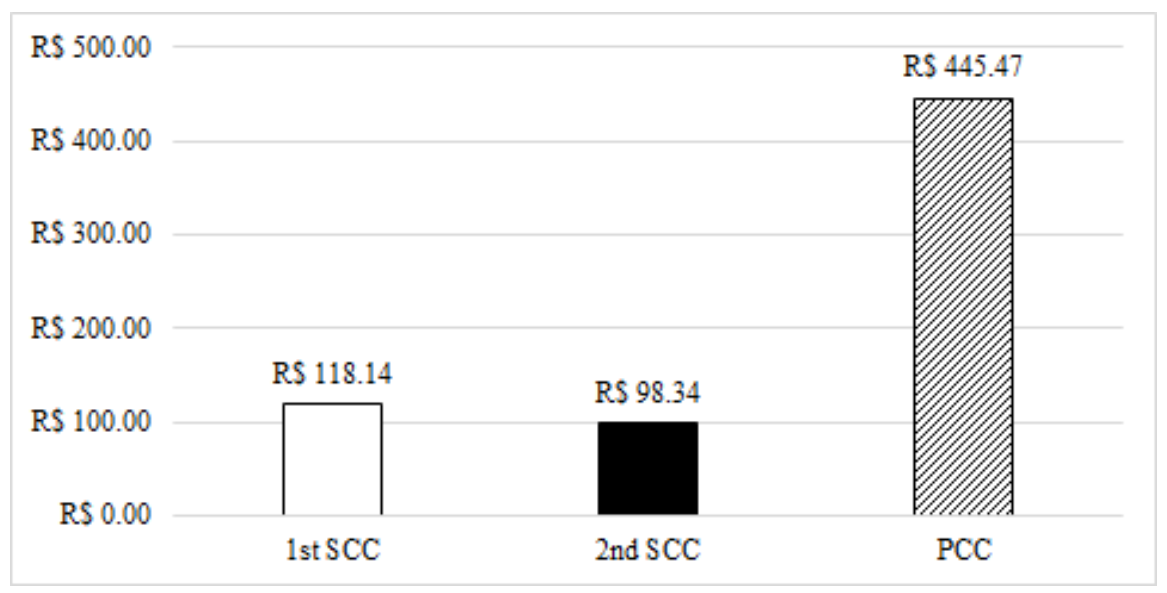

Graph 6. Comparison between labor cost for each pouring work.

Graph 7 shows the total labor costs spent on each concreting, considering the administration staff and the field team directly involved in the concreting. It can be seen that the cost of labor force decreased by $61 \%$ in the $1^{\text {st }}$ concreting with SCC and $64.7 \%$ in the $2^{\text {nd }}$ concreting with SCC, when compared to the labor cost of concreting with the PCC. Once again, these reductions in labor costs are the result of the faster pouring speed with the SCC and its easier spreading, leveling and finishing, thus reducing the pouring time, as already shown.

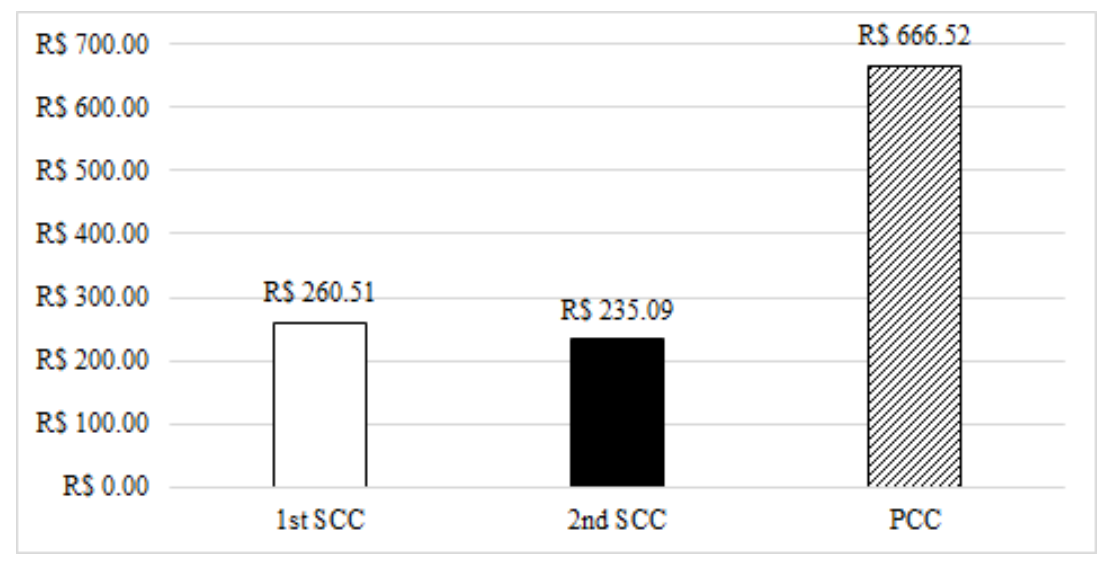

Graph 7. Total labor cost.

Graph 8 shows the result of the occupational accident risk index, in which it can be observed that the risk of accidents at work due to falls from a height when using the PCC is $211.11 \%$ higher than in the $1^{\text {st }}$ use of the SCC and $310,6 \%$ than in the $2^{\text {nd }}$ use of the SCC. This makes the use of SCC advantageous, as the reduction of accidents at work due to falls from a height is an incentive for employees and the company, positively impacting the market. The reduction in the risk factor for occupational accidents caused by the use of SCC is the result of the higher speed of concreting, 
leaving employees less exposed to the risk of accidents, and of the reduction in the number of employees involved in concreting.

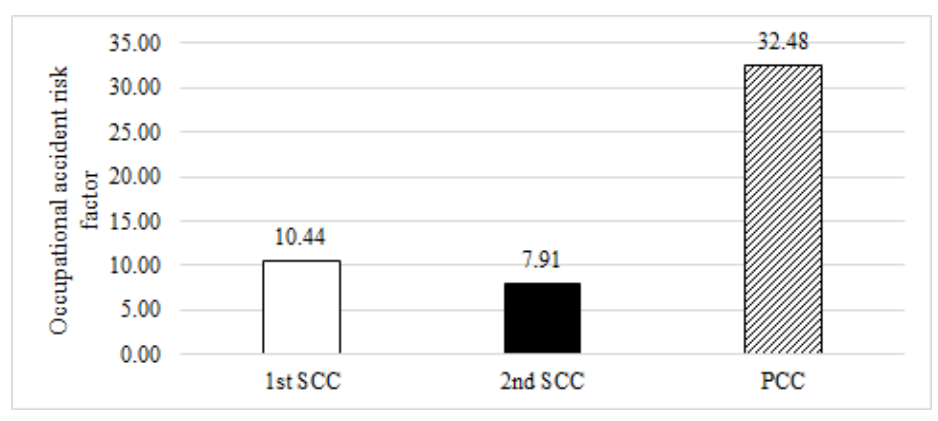

Graph 8. Occupational accident risk index.

If the construction uses the PCC, it is necessary to use vibrators to densify the concrete. In the present case study, the construction company used four vibrators in the concreting of the PCC, while in the concreting with the SCC, no vibrators were needed. Out of the four vibrators, two are for direct use and two are in standby, in case of any mishap, such as breakage or electrical failures. Table 9 shows the rental value of this equipment per day, an expense that is unnecessary when using the SCC.

Table 9. Spending with vibrator.

\begin{tabular}{cccc}
\hline Quantity & Occupation & Rental price (daily) & Total \\
\hline 02 & Use & $\mathrm{R} \$ 66.00$ & $\mathrm{R} \$ 132.00$ \\
\hline TOTAL & Reservation & $\mathrm{R} \$ 66.00$ & $\mathrm{R} \$ 132.00$ \\
\hline
\end{tabular}

The construction in study used two sets of moulds for the production of two slabs per month. To achieve this, it was necessary to wait 7 days to prestress the cables and start to deform the boxes and cover the ribs. With the use of SCC, the time for the prestressing can be reduced from 7 to 3 days, since at 3 days the concrete already has adequate strength to perform this procedure. This saves work time and possibly saves a mould set while maintaining the goal of achieving two slabs a month. According to the construction company, the amount spent only with the necessary materials, such as wood, boxes and ribbing, to execute a mould set is $\mathrm{R} \$ 107,734.50$, that is, it was seen that there is a possibility to save this value when using SCC.

Finally, Graph 9 shows the total cost of the cubic meter of the concrete used, already accounting the pouring, vibration (only for the PCC) and the finishing. The data considered for comparing the total cost was: the cost of the cubic meter of concrete, the volume of concrete, the cost of equipment and labor to achieve the accounted volume. It was also considered the amount spent with the rental of the mould set in the following proportion: one set of mould for the SCC and two sets of moulds for the PCC. 


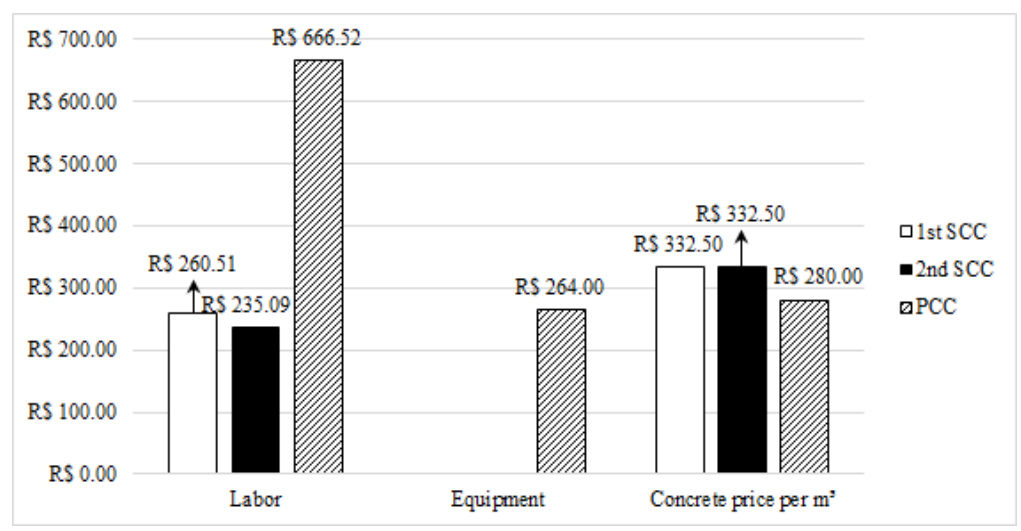

Graph 9. Cost per $\mathrm{m}^{3}$ of finished concrete.

As can be seen in Graph 9, the labor cost for concreting with SCC is, on average, 62.1\% cheaper than the cost of labor to build with PCC. This lower value is due to the smaller number of employees in concreting with SCC and the shorter concreting time. The cost of equipment is only accounted for concreting with PCC, since it uses vibrators. As concreting with SCC does not use vibrators, it has no equipment cost. Finally, it is possible to notice that the cubic meter of the SCC (only material, not poured) is $18.75 \%$ more expensive than that of the PCC. This overprice is justified by the higher consumption of cement and mineral addition to achieve self-compacting properties.

Table 10 shows a simulation for obtaining the total cost of the concreting work, considering that the building has 22 floors and $88 \mathrm{~m}^{3}$ of concrete is consumed on each floor.

Table 10. Comparison between the total cost of SCC and PCC.

\begin{tabular}{|c|c|c|c|c|}
\hline \multicolumn{5}{|c|}{$1^{\text {st }}$ SCC pouring } \\
\hline Costs & Quant. & $\mathbf{N}^{\circ}$ Floors & Unit Cost (R\$) & Total Cost (R\$) \\
\hline Labor & 1 day & 22 & 260.51 & $5,731.22$ \\
\hline Equipment & 0 & 22 & 0.00 & 0.00 \\
\hline Concrete & $88 \mathrm{~m}^{3}$ & 22 & 332.50 & $643,720.00$ \\
\hline Forms & 1 & - & $107,734.50$ & $107,734.50$ \\
\hline \multicolumn{4}{|c|}{ Total } & $757,185.72$ \\
\hline \multicolumn{5}{|c|}{$2^{\text {nd }}$ SCC pouring } \\
\hline Costs & Quant. & $\mathbf{N}^{\circ}$ Floors & Unit Cost (R\$) & Total Cost (R\$) \\
\hline Labor & 1 day & 22 & 235.09 & $5,171.98$ \\
\hline Equipment & 0 & 22 & 0.00 & 0.00 \\
\hline Concrete & $88 \mathrm{~m}^{3}$ & 22 & 332.50 & $643,720.00$ \\
\hline Forms & 1 & - & $107,734.50$ & $107,734.50$ \\
\hline \multicolumn{4}{|c|}{ Total } & $756,626.48$ \\
\hline \multicolumn{5}{|c|}{ PCC pouring } \\
\hline Costs & Quant. & $\mathbf{N}^{\circ}$ Floors & Unit Cost (R\$) & Total Cost (R\$) \\
\hline Labor & 1 day & 22 & 666.52 & $14,663.44$ \\
\hline Equipment & 1 day & 22 & 264.00 & $5,808.00$ \\
\hline Concrete & $88 \mathrm{~m}^{3}$ & 22 & 280.00 & $542,080.00$ \\
\hline Forms & 2 & - & $107,734.50$ & $215,469.00$ \\
\hline Total & & & & $778,020.44$ \\
\hline
\end{tabular}

According to data on Table 10, the labor and equipment costs of concreting with SCC are much lower than those of concreting with PCC, while the cost of PCC itself is much lower than the cost of SCC. Since it is consumed in large quantities, the cost of concrete is much more representative than the costs of labor and equipment. On the other hand, 
due to the fact that the SCC achieves high resistance in young ages and allows the use of only one set of moulds instead of two, as in concreting with PCC, there is a considerable cost reduction in this item for concreting with SCC. Thus, it appears that in the cost simulation to build the entire work with the SCC, it was only $2.7 \%$ cheaper than building the entire work with the PCC. Tutikian, Dal Molin and Cremonini (2005) evaluated the SCC cost they developed, verifying that it was $41 \%$ more expensive than the reference concrete. These authors did not consider the costs of labor, equipment and moulds in their work.

The cost of SCC can be further reduced by looking for cheaper fines to replace cement, as well as cheaper superplasticizer admixtures than the once used in this research.

\section{CONCLUSIONS}

According to the results obtained in the experimental part of this article, it can be concluded that:

- SCC already presents, at 3 days of age, on average, $90 \%$ of the $f_{c k}$ value of the concrete used in the study, allowing the prestressing to be advanced from 7 to 3 days of age. This allows the construction that uses this SCC to use only one set of moulds for concrete instead of two sets, as is the case with the use of PCC, reducing some of in the costs;

- The productivity of concreting with SCC, calculated by UPR, in worker-hours per cubic meter of concrete, is greater than the productivity of concreting with PCC, considering any of the three concreting times: only the time of casting the concrete, the launch time plus the waiting time between trucks, and the launch time plus the waiting time between trucks and the time for the concrete truck to arrive at the construction site.

- The number of workers employed in concreting per hour of work and per volume of concrete $\left(\mathrm{Wh} / \mathrm{m}^{3}\right)$ is about 3 times lower for concreting with SCC than for concreting with PCC. The explanation for the better performance of SCC is that, through this technology, fewer workers are needed in the concreting operation, aside from taking less time to pour the same volume of concrete;

- In the best scenario between the two concreting with SCC, the total pouring time with this type of concrete came to be in the order of half the total pouring time with the PCC. However, the waiting time of the concrete mixer truck with the SCC was $134 \%$ longer, on average, than the waiting time of the concrete mixer truck with the PCC;

- The SCC's launch, vibrating and sealing time was 39.4\% less, on average, than the time taken to carry out these activities with the PCC. This reduction in time meant that the cost of administration personnel was reduced by $36.9 \%$, on average;

- The cost of labor involved in concreting was reduced by 50\%, on average, when using the SCC due to the lack of need of employees who handled the vibrators, the electrician's assistant who was on standby for any damage and due to the ease of spreading the SCC, the number of workers who pulled and lathed the concrete was reduced by almost half, along with the number of carpenters, given that the SCC did not accumulate on the moulds, reducing the risk of their rupture;

- The index called occupational accident risk factor was reduced by $71.8 \%$ when concreting with the SCC as a result of the higher speed of concreting, leaving employees less exposed to the risk of accidents, and reduction in the number of employees involved in concreting with this type of concrete;

- The cost of concreting with SCC, considering that the building has 22 floors and $88 \mathrm{~m}^{3}$ of concrete is used on each floor, was $2.7 \%$ lower than the cost of concreting with the PCC.

\section{ACKNOWLEDGEMENTS}

The authors would like to thank JVS Engenharia for the support in providing a construction site for the application of the SCC and the Research Group on Construction Materials and Structures (GPMATE) at the Federal University of Ceará (UFC) for their support in carrying out the tests on site and in the laboratory.

\section{REFERENCES}

[1] W. L. Repette, “Concreto autoadensável,” in Concreto: Ciência e Tecnologia, G. C. Isaia, Ed., São Paulo: Ibracon, 2011, ch. 48, pp. $1169-1806$.

[2] P. C. Gomes and A. R. Barros, Métodos de Dosagem de Concreto Autoadensável, São Paulo: Pini, 2009.

[3] EFNARC, Specification and Guidelines for Self-Compacting Concrete. Surrey, UK, Concrete, Association House, 2002.

[4] F. M. Almeida Fo., "Contribuição ao estudo da aderência entre barras de aço e concretos autoadensáveis," Ph.D. dissertation, Escola de Engenharia de São Carlos, USP, São Paulo, 2006.

[5] B. F. Tutikian, "Métodos para dosagem de concretos autoadensáveis,” M.S. thesis, UFRGS, Porto Alegre, 2004. 
[6] B. F. Tutikian and D. C. Dal Molin, Concreto Autoadensável, São Paulo: Pini, 2008.

[7] H. R. Thomas and I. Ylakoumis, "Factor model of construction productivity," J. Constr. Eng. Manage., 1987.

[8] B. F. Tutikian, D. Dal Molin, and R. Cremonini, "Viabilização econômica do concreto audensável," in $12^{\circ}$ Concurso Falcão Bauer. Câmara Brasileira da Indústria da Construção Civil, 2005.

[9] P. C. C. Gomes, "Optimization and characterization of high-strength self-compacting concrete," Ph.D. dissertation, Escola Técnica Superior D’Enginyers de Camins, UPC, Espanha, 2002, p. 139.

[10] U. E. L. Souza, Como Aumentar a Eficiência da Mão de Obra, São Paulo: Pini, 2006.

[11] M. M. Dantas and U. S. Souza "Produtividade e consumo na concretagem: comparação quanto a execução do serviço sob condições diversas," in III SIBRAGEC, São Carlos, 2003.

Author contributions: J. H. F. Serra: conceptualization, methodology, experimental procedures, data acquisition and curation, analysis, writing. A. E. B. Cabral: conceptualization, methodology, funding acquisition, supervision, writing.

Editors: José Tadeu Balbo, José Luiz Antunes de Oliveira e Sousa, Guilherme Aris Parsekian. 